\title{
A REVIEW OF REGENERATIVE ENDODONTICS: CURRENT PROTOCOLS AND FUTURE DIRECTIONS
}

\author{
Rejeneratif Endodonti Üzerine Bir Derleme: Güncel Protokoller ve Geleceğe Yönelik \\ Öneriler
}

\author{
Louis M. LIN ${ }^{1}$, Bill KAHLER ${ }^{2}$
}

Received: 04/09/2017

Accepted:10/10/2017

\section{ABSTRACT}

This review outlines the biological basis and clinical protocols currently used in regenerative endodontic procedures (REPS) and discuss future directions in pulp regeneration approaches. The treatment of immature teeth with REPs has been described as a 'paradigm shift' as there is the potential for further root maturation. Clinically, REPs involve disinfection of the root canal system without damaging the endogenous stem cell potential present in the apical papilla and other tissues. These stems cells are introduced into the root canal space by inducing a blood clot followed by placement of an intracanal barrier to prevent microleakage. The biological concept of REPS involves the triad of stem cells, scaffold and signalling molecules. Currently, repair rather than true regeneration of the 'pulp-dentine complex' is achieved and further root maturation is variable. However, may clinicians consider the treatment of teeth with REPs as the optimal treatment approach for immature teeth with pulp necrosis.

Keywords: Regenerative endodontic protocols, immature teeth; pulp necrosis; root maturation; triple antibiotic paste; calcium hydroxide
$\ddot{O} Z$

Bu derlemede rejeneratif endodontik tedavinin biyolojik temelleri ve güncel klinik protokolleri anlatılmakta ve pulpa rejenerasyonu yaklaşımlarının geleceği tartışılmaktadır. Kök ucu kapanmamış dişlerin rejeneratif endodontik tedavi ile kök gelişiminin devam etme potansiyeli köklü bir değişim yaratmıştır. Klinik olarak rejeneratif endodontik tedavi apikal papilla ve diğer dokularda bulunan endojen kök hücrelere zarar vermeden kök kanalı sisteminin dezenfeksiyonunu içerir. Bu kök hücrelerin kan pıhtısı oluşturulması ile kök kanalı içine taşınmasını takiben mikrosızıntıyı önleme amacıyla kanal içine bariyer malzemesi yerleştirilir. Rejeneratif endodontik tedavinin biyolojik prensibi kök hücreler, doku iskeleleri ve sinyal molekülleri triadından oluşur. Günümüzde, "pulpa-dentin kompleksi" nin gerçek rejenerasyonundan ziyade tamir gerçekleşmektedir ve kök gelişiminin tamamlanması ise değişkenlik göstermektedir. Ancak, birçok klinisyen pulpası nekroze kök gelişimi tamamlanmamış dişlerde en uygun tedavinin rejeneratif endodontik yaklaşımlarla sağlanabileceğini düşünmektedir.

Anahtar kelimeler: Rejeneratif endodontik tedavi protokolleri; kök gelişimi tamamlanmamış dişler; pulpa nekrozu; kök gelişimi; ̧̧̈̈lü antibiyotik pat; kalsiyum hidroksit

\footnotetext{
Department of Endodontics New York University College of Dentistry 345 East 24th Street New York, NY 10010 USA

${ }^{2}$ School of Dentistry The University of Queensland Oral Health Centre 288 Herston Road, Corner Bramston Terrace \& Herston Road Herston QLD 4006 Australia
} 


\section{Introduction}

Regenerative endodontics is an exciting and developing field in the treatment of immature teeth with infected root canals that has been described as a "paradigm shift" in the management of these teeth and can result in continued root maturation and apical closure (1-3). Traditional approaches of calcium hydroxide apexification and apical barrier techniques with mineral trioxide aggregate (MTA) have been used in the treatment of immature teeth with pulp necrosis though generally there is no further root development so the roots remain thin and fragile with a higher risk of fracture and tooth loss. Recently, it has been suggested that regenerative endodontic protocols (REPs) that utilize endogenous stem cells that are introduced in the canal by lacerating the periapical tissues to fill the canal with blood should be used for the treatment of immature teeth with pulp necrosis (4). Regenerative endodontics has been defined as "biologically based procedures designed to replace damaged structures, including dentin and root structures, as well as cells of the pulp-dentin complex" (4). The clinical considerations for regenerative endodontic protocols are (1) disinfection of the root canal system (2), provision of a scaffold which often involves laceration of the periapical tissue to induce a blood clot and introduce stem cell activity within the root canal (3), and an adequate coronal seal to prevent reinfection (5-10). The assumption is that regenerative endodontic protocols which result in continued root maturation mean the teeth and roots are not as inherently weak and susceptible to fracture as the traditional techniques of $\mathrm{Ca}(\mathrm{OH}) 2$ apexification and MTA barrier placements. Studies which have compared REPs with the traditional approaches of calcium hydroxide apexification and MTA apical barrier techniques have shown comparable outcomes $(11,12)$. However, another study that compared the traditional and regenerative protocols showed revascularization was associated with significantly greater increases in root length and thickness compared with calcium hydroxide apexification and MTA barrier placement as well as higher overall survival rates (13).

\section{Terminology}

A number of terms have been adopted in the literature with regenerative endodontics, revascularization and revitalization being the most commonly used. The term 'revascularization' is well established in the endodontic literature and relates to the reestablishment of vascularity in the pulp space after traumatic injuries that sever the blood supply to the pulp of immature teeth $(14,15)$. Earlier reports on this new technique showed renewed root maturation in infected immature teeth and described the introduction of a blood clot into the root canal as "revascularization" $(16,17)$. Regenerative endodontics implies that further root maturation results in reestablishment of the pulp dentine complex. Many studies show that this is not the case with a variety of tissues such as dentine, cementum, periodontal ligament, bone, osteoid and possibly pulp being the tissue found in treated teeth with regenerative endodontic protocols, suggesting 'repair' rather than 'regeneration' (18-20).

'Revitalization' has been suggested as it describes non-specific vital tissue rather than just blood vessels as implied by the term 'revascularization' (21).

The term regenerative endodontic procedures (REPs) has been widely adopted and refers to all procedures that aim to attain organized repair of the dental pulp and include future therapies yet to evolve in the field of regenerative endodontics (6).

\section{Regeneration or repair}

Tissue injury caused by infection or trauma after appropriate treatment will result in healing by either regeneration or repair (22). Regeneration is defined as reconstitution of damaged tissue by tissue similar to original tissue and restoration of biological functions $(22,23)$. Repair is replacement of damaged tissue by tissue different from original tissue and loss of biological functions $(22,23)$. The dental pulp has a limited potential of regeneration (24). In regenerative endodontic procedures, many growth factors embedded in the dentin matrix are released into the canal space after EDTA treatment (25). These growth factors have been shown to be able to signal pulp stem cells to differentiate into odontoblast-like cells and produce reparative dentin (26-29). However, the mesenchymal stem cells (30) introduced into the canal space during regenerative endodontic procedures do not appear to be able to differentiate into odontoblast-like cells and produce the dentin-pulp complex in many animal and human studies.

Histologic characterization of tissues formed in the canal space

Many histological studies of regenerative 
Lin LM \& Kahler B

endodontic procedures of immature teeth with necrotic pulps and apical periodontitis have been investigated in animal models and humans and show that the tissues formed in the canal space were mineralized tissue similar to cementum and bone, and fibrous connective tissue resembling periodontal ligament (18, 20, 31-34).

Histologically, regenerative endodontic procedures of human immature permanent teeth with necrotic pulp are considered a reparative and not a regenerative process $(35,36)$. Radiographic thickening of the canal walls, and continued root maturation of immature permanent teeth with necrotic pulps after regenerative endodontic procedures should not be regarded as a regeneration of dentin-pulp complex without histological confirmation. If the primary goal of regenerative endodontic procedures is elimination of clinical symptom/sign and resolution of apical periodontitis (37), then repair, although not an ideal wound healing, is not a treatment failure $(35,36)$.

\section{History}

The promise and potential of regenerative endodontic therapies in necrotic teeth was first explored by Nygaard-Östby in 1961 who investigated the potential for repair when bleeding was induced by over-instrumentation beyond the apex prior to partial root filling of the canal with limited success (38). Forty years later, in 2001 Iwaya et al. (17) reported a case using a procedure termed 'revascularization', on an infected necrotic immature premolar tooth that showed continued root maturation and thickening of root canal walls with mineralized tissue. Subsequent case reports also demonstrated the efficacy of this technique primarily in premolar teeth when using a triple-antibiotic paste $(16,39,40)$ or calcium hydroxide $(1,41)$. Further reports demonstrated successful outcomes in traumatized central incisor teeth $(21,42-44)$.

A number of authors have described regenerative endodontic techniques as a "paradigm shift" in the treatment of immature teeth with necrotic pulps (1-3).

Clinical considerations for regenerative endodontic procedures

\section{Young patient}

Whilst REPs have been utilised on mature teeth (45-47), the vast majority of reported cases are undertaken on young patients with immature infected teeth where cessation of root maturation has occurred as a consequence of pulp necrosis. The American Association of Endodontists (AAE) clinical considerations for regenerative endodontic procedures define success by three measures (37): Primary goal (essential): The elimination of symptoms and the evidence of bony healing Secondary goal (desirable): Increased root wall thickness and/or increased root length Tertiary goal: positive response to vitality testing (48) Whilst the primary goal is an objective for all endodontic treatments, it is the secondary goal of increased width and/or length that is pertinent in the immature tooth. The assumption is that further root maturation often assessed in conjunction with apical closure of the immature root apex may minimise the incidence of root fracture. Another assumption is in the tertiary goal that a return of neural capacity may indicate a more organized vital pulp tissue (37). In 2013, a review reported many cases demonstrated a positive response to pulp sensibility testing (6).

\section{Minimal or no instrumentation of the dentinal} walls

REPs advocate minimal or no filing of the canal (49). However, in a histologic and histobacteriologic study of a failed REP treatment most bacteria were noted in the apical and not the coronal portion of the canal where a biofilm had formed on the canal walls and penetrated into the dentinal tubules. The authors concluded that on the basis of the histobacteriologic findings that some degree of mechanical debridement may also be required to disrupt biofilm on the canal walls for continued root maturation to occur (49).

\section{Disinfection of the root canal system}

Disinfection of the root canal system is thought to be critical to the success of REPs as infection prevents regeneration, repair and stem cell activity $(49,50)$. Chemical disinfection of the root canal system is not solely dependent on bacteriocidal/ bacteriostatic properties of the agents as these irrigants/medicaments should not damage the survival and proliferative capacity of the patient's stem cells (6). As few case reports have been performed in a single visit (51-53), the protocol describes a two-visit approach with the use of irrigants and an intra-canal medicament (to be discussed in the next subsection). The guidelines suggest copious irrigation with $20 \mathrm{ml}$ sodium hypochlorite $(\mathrm{NaOCl})$ using an irrigation system that minimizes the possibility of extrusion of 
irrigants into the periapical space (e.g., needle with closed end and side-vents, or EndoVac $\left.{ }^{\mathrm{TM}}\right)$. Lower concentrations of $\mathrm{NaOCl}$ are advised (1.5\% sodium hypochlorite $(20 \mathrm{~mL} / \mathrm{canal}, 5 \mathrm{~min})$ and then irrigated with saline or EDTA $(20 \mathrm{~mL} /$ canal, $5 \mathrm{~min})$ with the irrigating needle positioned about $1 \mathrm{~mm}$ from the root end to minimize cytotoxicity to stem cells in the apical tissues (37). Growth factors contained in the dentine matrix are released by endodontic irrigants $(25,54,55)$. Lower concentrations of $\mathrm{NaOCl}$ are now recommended as higher concentration significantly decreases the survival of stem cells of the apical papilla (SCAP) $(56,57)$. A concentration of $1.5 \%$ $\mathrm{NaOCl}$ had minimal destructive effects on SCAP (56). Furthermore the use of 17\% EDTA resulted in increased SCAP survival expression as well as partially reversing the deleterious effects of $\mathrm{NaOCl}$ (56). EDTA acts to demineralise the dentine and expose the dentine matrix which acts to release growth factors from the dentine matrix $(25,34,55)$. EDTA conditioning of dentin promoted the adhesion, migration and differentiation of dental pulp stem cells towards or onto dentin (55). Exposure of the dentin matrix by EDTA also appeared to increase the adherence of newly formed mineralized tissue to the root walls (34). Therefore, a final rinse with EDTA before creation of a blood clot is advised $(25,55)$.

\section{Placement of an intra-canal medicament}

The first report of revascularization in an infected immature tooth in 2001 used a double antibiotic paste of metronidazole and ciprofloxacin (17). The next report used a combination of metronidazole, ciprofloxacin and minocycline often referred to as ' 3 mix' or 'triple antibiotic paste' (TAP) (6). The rationale for the use of TAP was a number of studies of endodontic infections in deciduous teeth where a combination of metronidazole, ciprofloxacin and minocycline at a concentration of $100 \mu \mathrm{g} / \mathrm{mL}$ of each drug completely eliminated cultivatable bacteria from infected root canals in vitro and in vivo $(58,59)$. Triple antibiotic pastes using this combination of antibiotics have been shown to reliably disinfect dentine in infected root canals with diffusion of the drugs throughout the entire root dentine $(60,61)$. The AAE protocol recommends TAPs at concentrations no greater than $0.1 \mathrm{mg} / \mathrm{mL}$ (37). At this concentration, TAP is conducive with stem cell survival and proliferation (19) and also effective in eliminating microorganisms within the root canal $(58,59)$. AAE guidelines also recommended calcium hydroxide (37). Calcium hydroxide has been shown to be conducive to SCAP survival and proliferation (62). Furthermore a study has shown that SCAPs had the highest survival when cultured on dentine exposed to calcium hydroxide when compared to dentine exposed to concentrations of $1 \mathrm{mg} / \mathrm{mL}$ or higher TAP (63). Clinically, an analysis of case reports that used calcium hydroxide as an intracanal medicament showed further root maturation (64). Thus the concentrations of both irrigants and medicaments are important to find the balance between disinfection of the canal, alteration of the dentine matrix for the release of growth factors and survival and proliferation of SCAP.

Creation of a blood clot or protein scaffold in canal

After disinfection of the canal and resolution of symptoms, REPs usually involve lacerating the periapical tissues to initiate bleeding or the use of platelet-rich plasma (PRP) or platelet-rich fibrin (PRF). An important study demonstrated that the evoked-bleeding step in regenerative procedures triggers a significant accumulation of undifferentiated stem cells into the canal space (30). Contemporary regenerative endodontics follows principles of bioengineering with the foundation dependent on the interaction of stem cells, scaffolds and growth factors (65).

\section{Effective coronal seal}

Once a blood clot or scaffold is in place within the canal, a coronal barrier is placed to prevent coronal leakage of microorganisms. Current protocols recommend that when a blood clot is formed, a premeasured piece of Collaplug (Zimmer Dental Inc, Warsaw, IN) should be carefully placed on top of the blood clot to serve as an internal matrix for the placement of approximately $3 \mathrm{~mm}$ of white MTA (Dentsply, Tulsa, OK) followed by a 3-4 mm layer of glass ionomer layer (eg, Fuji IX; GC America, Alsip, IL, or other) is placed over the MTA. A bonded reinforced composite resin restoration (e. g., Z-100; 3M, St Paul, MN, or other) is then placed over the glass ionomer (37). MTA is a biocompatible material with bioactive properties that resists bacterial contamination (66). Biodentine ${ }^{\circledR}$ (Septodont, Lancasted, PA, USA) can be used as an alternative calcium silicate-based cement (67). 
Lin LM \& Kahler B

\section{Clinical regenerative endodontic procedures}

As aforementioned, regenerative endodontic procedures for immature permanent teeth with noninfected and infected necrotic pulps in humans varies considerably in terms of concentrations of sodium hypochlorite irrigant and triple antibiotic paste in all published studies. There is no standard protocol of REP. The American Association of Endodontists suggests a Clinical Considerations for a Regenerative Procedure for its members (37).

Table 1. Regenerative endodontic procedures (37).

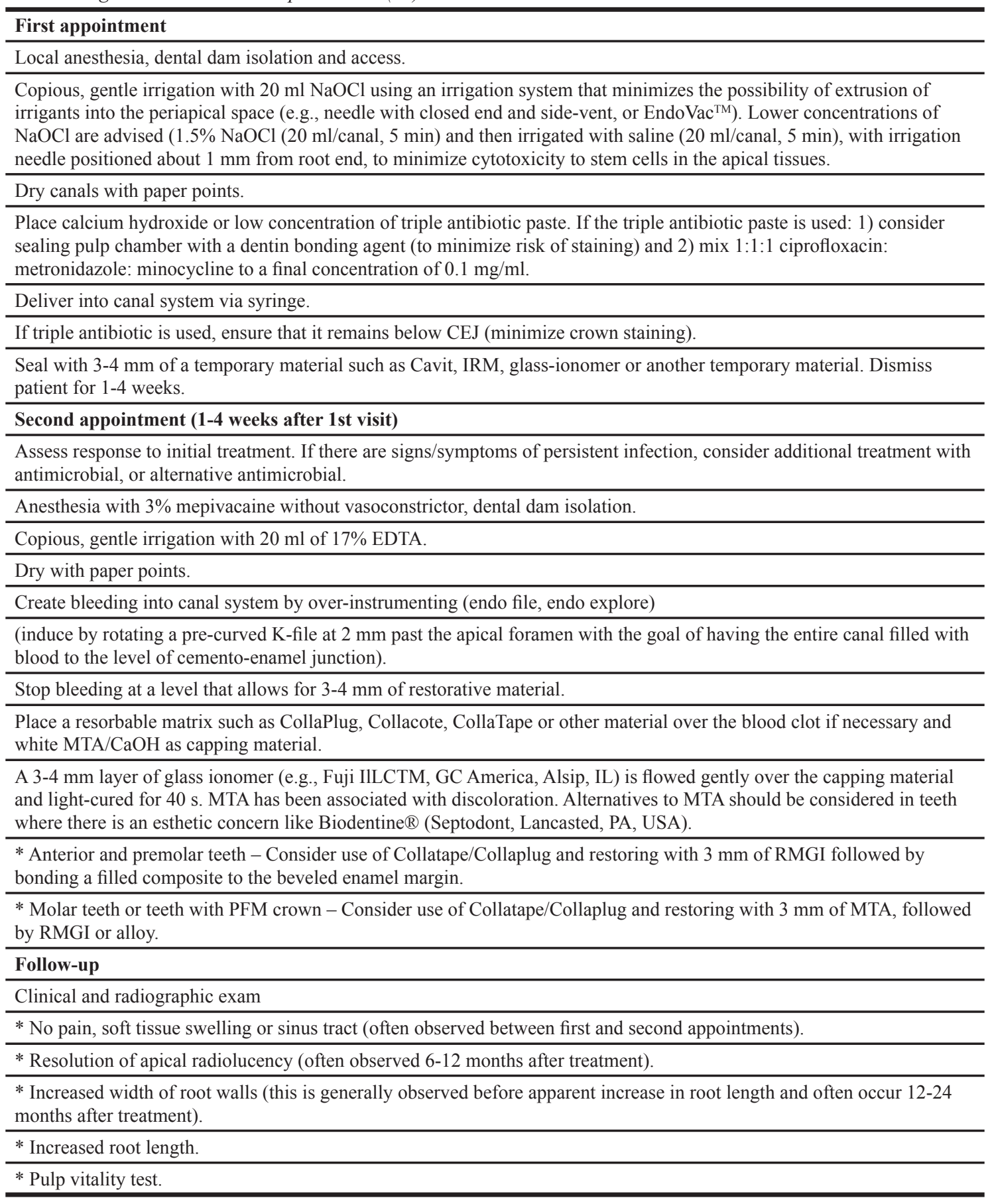




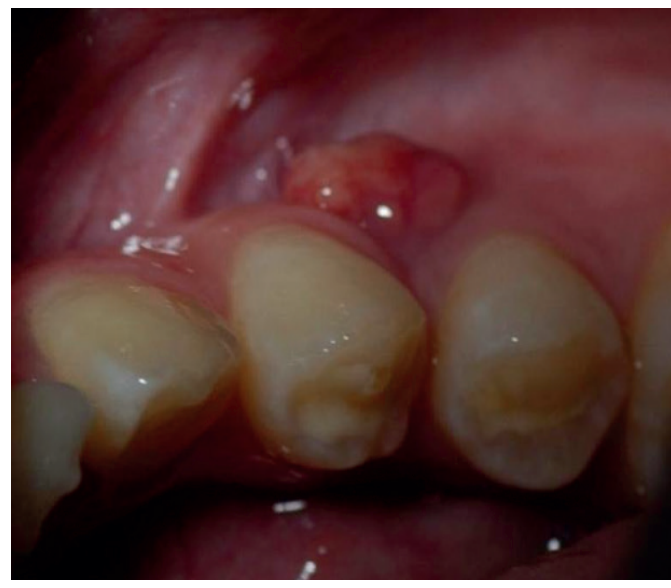

Figure 1. A mandibular premolar tooth where the evaginatus has fractured causing pulp necrosis and chronic abscess.



Figure 2. A GP marker tracks to the periapical tissues of an immature root.



Figure 3. A blood clot was induced into the canal to the level of the cemento-enamel junction after a disinfection protocol four weeks earlier that employed 1\% sodium hypochlorite and the canal was then medicated with a triple antibiotic paste consisting of metronidazole, ciprofloxacin and amoxicillin.

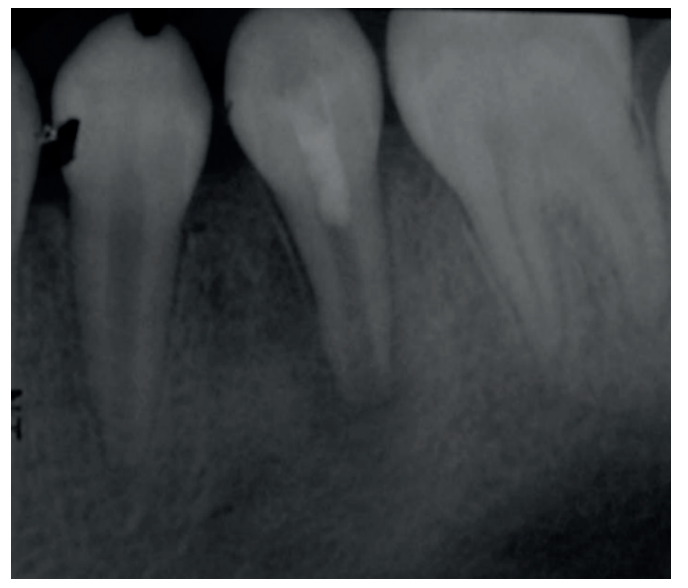

Figure 4. A radiograph showing an intracanal barrier of MTA placed on the blood clot. The tooth was restored with glass ionomer cement and composite resin.

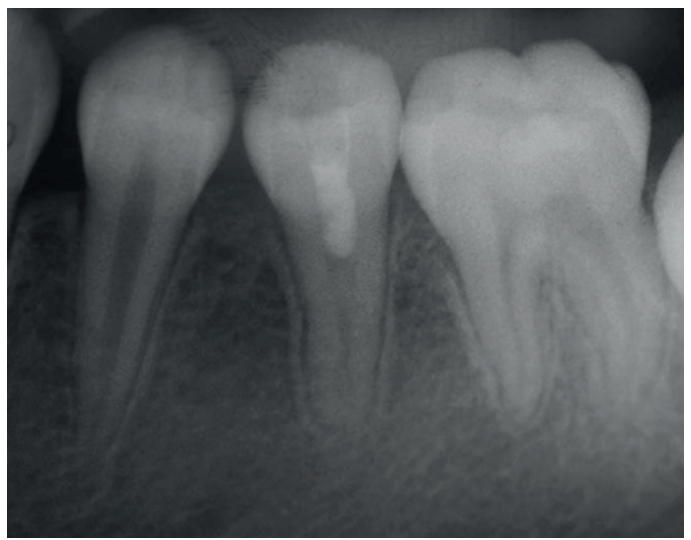

Figure 5. A radiograph taken at an 18 month review showing resolution of the apical periodontitis as well as further root maturation indicated by increased with of the root dentine walls and apical closure.

\section{Outcome assessment}

In 2014, there were 51 publications of clinical studies that employed regenerative endodontic protocols with 255 teeth treated. There were 2 high-level cohort studies (LOE 2), 8 case series (LOE 4) and 41 case reports (LOE 5) (68).

Is revascularization an effective and reproducible technique?

A recent systematic review reported that 97 of 101 teeth (96\%) treated with REPs between 2001 and 2014 were successfully treated as measured by some degree of apexogenesis including increased root length, increased root thickness and apical closure. Only 4 
Lin LM \& Kahler B

teeth $(4 \%)$ failed to show no further root maturation. Apical closure was detected in $55.4 \%$ of teeth with increased root length (76.2\%) and increased root width (79.2\%) reported more frequently. These outcomes were independent of clinical variables such as operator and material selection or differences in protocols (69).

Radiographic responses of teeth treated with REPS

Chen et al. (70) described 5 types of responses for teeth treated with REPs. Type 1 where there is increased thickening of the canal walls and continued root maturation. Type 2 where there is no significant continuation of root development with the root apex becoming blunt and closed. Type 3 where there is continued root development with the apical foramen remaining open. Type 4 where there is severe calcification (obliteration) of the canal space. Type 5 where there is a hard tissue barrier formed in the canal between the coronal MTA plug and the root apex (70).

\section{Discoloration}

Many studies have shown that discoloration is a significant problem following regenerative endodontic treatment (71). This is of particular concern for traumatized anterior teeth as appearance and pleasing aesthetics are patient centered outcomes. Discoloration is more often associated with TAP that includes minocycline though discoloration has also been reported with calcium hydroxide. MTA which is the most commonly used material as an intacanal barrier has also been shown to discolor teeth (72). Therefore patients should be advised that discoloration of the tooth is often associated with REPs as stated in the AAE guidelines (37).

\section{Follow-up}

Most studies have undertaken 6-month radiographic reviews for 12-18 months and longer to make assessment of periapical healing and for further root maturation.

\section{What does the future hold?}

Currently, there are two approaches to pulp tissue regeneration in regenerative endodontics, namely cellfree and cell-based. Both approaches are based on the concept of tissue engineering applying stem cells, bioactive growth/differentiation factors and biomimetic scaffold. Clinical regenerative endodontic procedures can be considered a cell-free approach. The cell-based approach requires isolation and ex vivo expansion of stem cells seeded in the scaffold and then transplanted into the canal space (73-79). Technically, the cell-free approach is simpler than cell-based approach because the former does not have to be concerned about stem cell source, and isolation. However, in the cell-free approach the endogenous stem cells are not pulp tissue specific and can be from apical papilla, periodontal ligament or bone marrow. The cell-based approach employs pulp tissue specific stem cells, such as dental pulp stem cells (DPSCs) (80), stem cells from exfoliated deciduous teeth (81), and stem cells from apical papilla (82).

These stem cells have been shown to be capable of differentiating into odontoblast-like cells and produce dentine-like mineralized tissue (80-82). Therefore, this approach has more promise to result in true regeneration. Nevertheless, several problems are associated with cell-based approach and have to be resolved, such as limited availability of stem cell source, isolation and ex vivo expansion of stem cells, good manufacturing practice facilities, contamination, stem cell bank, cost, regulatory issues and clinician's ability to perform stem cell transplantation $(83,84)$. Basically, both cell-free and cell-based approaches of pulp tissue regeneration are still in the preclinical stage of experiments (84). However, from future prospect pulp tissue regeneration appears to be an attainable goal, based on the concept of stem cell-based pulp tissue engineering (85).

\section{Conclusion}

Regenerative endodontics presents a new era in biological and clinical endodontics. Currently, this biologically based treatment is being recognized as the first treatment choice for immature teeth with pulp necrosis based on the success of many published cases in the literature. Our understanding of the clinical protocols has evolved to eliminate pulp infection and to also allow for stem cell potential to be induced in the canal and for the release of growth factors fossilized in the dentine walls. While repair rather than true regeneration is achieved with current protocols, it is hoped that further research in the area of stem cell-based pulp engineering will allow for true regeneration and improved treatment outcomes.

\section{Source of funding}

None declared. 
Conflict of interest

None declared.

\section{References}

1. Chueh LH, Huang GT. Immature teeth with periradicular periodontitis or abscess undergoing apexogenesis: A paradigm shift. J Endod 2006;32(12):1205-1213.

2. Huang GT. A paradigm shift in endodontic management of immature teeth: Conservation of stem cells for regeneration. J Dent 2008;36(6):379-386.

3. Huang GT, Sonoyama W, Liu Y, Liu H, Wang S, Shi S. The hidden treasure in apical papilla: The potential role in pulp/dentin regeneration and bioroot engineering. J Endod 2008;34(6):645651.

4. Diogenes A, Ruparel NB, Shiloah Y, Hargreaves KM. Regenerative endodontics: A way forward. J Am Dent Assoc 2016;147(5):372-380.

5. Bezgin T, Sonmez H. Review of current concepts of revascularization/revitalization. Dent Traumatol 2015;31(4):267-273.

6. Diogenes A, Henry MA, Teixeira FB, Hargreaves KM. An update on clinical regenerative endodontics. Endod Topics 2013;28(1):2-23.

7. Galler KM. Clinical procedures for revitalization: Current knowledge and considerations. Int Endod J 2016;49(10):926-936.

8. Hargreaves KM, Giesler T, Henry M, Wang Y. Regeneration potential of the young permanent tooth: What does the future hold? J Endod 2008;34(7 Suppl):S51-56.

9. Kontakiotis EG, Filippatos CG, Tzanetakis GN, Agrafioti A. Regenerative endodontic therapy: A data analysis of clinical protocols. J Endod 2015;41(2):146-154.

10. Murray PE, Garcia-Godoy F, Hargreaves KM. Regenerative endodontics: A review of current status and a call for action. J Endod 2007;33(4):377-390.

11. AlobaidAS, Cortes LM, Lo J, Nguyen TT, Albert J, Abu-Melha AS, Lin LM, Gibbs JL. Radiographic and clinical outcomes of the treatment of immature permanent teeth by revascularization or apexification: A pilot retrospective cohort study. J Endod 2014;40(8):1063-1070.

12. Kahler B, Rossi-Fedele G, Chugal N, Lin LM. An evidence-based review of the efficacy of treatment approaches for immature permanent teeth with pulp necrosis. J Endod 2017;43(7):1052-1057.

13. Jeeruphan T, Jantarat J, Yanpiset K, Suwannapan L, Khewsawai P, Hargreaves KM. Mahidol study 1: Comparison of radiographic and survival outcomes of immature teeth treated with either regenerative endodontic or apexification methods: A retrospective study. J Endod 2012;38(10):1330-1336.

14. Andreasen JO, Andreasen FM. Textbook and color atlas of traumatic injuries to the teeth. Copenhagen: Munsgaard, 1994.

15. Huang GT, Lin LM. Letter to the editor: Comments on the use of the term "revascularization" to describe root regeneration. J Endod 2008;34(5):511; author reply 511-512.

16. Banchs F, Trope M. Revascularization of immature permanent teeth with apical periodontitis: New treatment protocol? J Endod 2004;30(4):196-200.

17. Iwaya SI, Ikawa M, Kubota M. Revascularization of an immature permanent tooth with apical periodontitis and sinus tract. Dent Traumatol 2001;17(4):185-187.

18. Becerra P, Ricucci D, Loghin S, Gibbs JL, Lin LM. Histologic study of a human immature permanent premolar with chronic apical abscess after revascularization/revitalization. J Endod 2014;40(1):133-139.

19. Martin G, Ricucci D, Gibbs JL, Lin LM. Histological findings of revascularized/ revitalized immature permanent molar with apical periodontitis using platelet-rich plasma. J Endod 2013;39(1):138-144.

20. Wang X, Thibodeau B, Trope M, Lin LM, Huang GT. Histologic characterization of regenerated tissues in canal space after the revitalization/ revascularization procedure of immature dog teeth with apical periodontitis. J Endod 2010;36(1):56-63.

21. Lenzi R, Trope M. Revitalization procedures in two traumatized incisors with different biological outcomes. J Endod 2012;38(3):411-414.

22. Kumar V, Abbas AK, Fausto N, et al. Robbins and cotran pathologic basis of disease. Philadelphia, PA: Saunders, $9^{\text {th }}$ ed. 2014.

23. Majno G, Joris I. Cells, tissues, and disease. Oxford, London: Oxford University Press, $2^{\text {nd }}$ ed. 2004.

24. Shi S, Bartold PM, Miura M, Seo BM, Robey PG, Gronthos S. The efficacy of mesenchymal stem cells to regenerate and repair dental structures. 
Lin LM \& Kahler B

Orthod Craniofac Res 2005;8(3):191-199.

25. Galler KM, Buchalla W, Hiller KA, Federlin M, Eidt A, Schiefersteiner M, Schmalz G. Influence of root canal disinfectants on growth factor release from dentin. J Endod 2015;41(3):363-368.

26. Nakashima M, Nagasawa H, Yamada Y, Reddi AH. Regulatory role of transforming growth factor-beta, bone morphogenetic protein-2, and protein- 4 on gene expression of extracellular matrix proteins and differentiation of dental pulp cells. Dev Biol 1994;162(1):18-28.

27. Rutherford RB, Wahle J, Tucker M, Rueger $\mathrm{D}$, Charette $\mathrm{M}$. Induction of reparative dentine formation in monkeys by recombinant human osteogenic protein-1. Arch Oral Biol 1993;38(7):571-576.

28. Sloan AJ, Smith AJ. Stimulation of the dentinepulp complex of rat incisor teeth by transforming growth factor-beta isoforms 1-3 in vitro. Arch Oral Biol 1999;44(2):149-156.

29. Tzaifas D AA, Papadimitrious S, Gasic J, Komnenou A. 1998;43(6):431-444. Effects of recombinant basic fibroblast growth factor, insulin-like growth factor-11 and transforming growth factor- $\beta 1$ on dog dental pulp cells in vivo. Arch Oral Biol 1998;43(6):431-444.

30. Lovelace TW, Henry MA, Hargreaves KM, Diogenes A. Evaluation of the delivery of mesenchymal stem cells into the root canal space of necrotic immature teeth after clinical regenerative endodontic procedure. J Endod 2011;37(2):133-138.

31. da Silva LA, Nelson-Filho P, da Silva RA, Flores DS, Heilborn C, Johnson JD, Cohenca N. Revascularization and periapical repair after endodontic treatment using apical negative pressure irrigation versus conventional irrigation plus triantibiotic intracanal dressing in dogs' teeth with apical periodontitis. Oral Surg Oral Med Oral Pathol Oral Radiol Endod 2010;109(5):779787.

32. Lei L, Chen Y, Zhou R, Huang X, Cai Z. Histologic and immunohistochemical findings of a human immature permanent tooth with apical periodontitis after regenerative endodontic treatment. J Endod 2015;41(7):1172-1179.

33. Shimizu E, Ricucci D, Albert J, Alobaid AS, Gibbs JL, Huang GT, Lin LM. Clinical, radiographic, and histological observation of a human immature permanent tooth with chronic apical abscess after revitalization treatment. J
Endod 2013;39(8):1078-1083.

34. Yamauchi N, Yamauchi S, Nagaoka H, Duggan D, Zhong S, Lee SM, Teixeira FB, Yamauchi M. Tissue engineering strategies for immature teeth with apical periodontitis. J Endod 2011;37(3):390397.

35. Lin LM, Rosenberg PA. Repair and regeneration in endodontics. Int Endod J 2011;44(10):889-906.

36. Simon SR, Tomson PL, Berdal A. Regenerative endodontics: Regeneration or repair? J Endod 2014;40(4 Suppl):S70-75.

37. American Association of Endodontists. AAE Clinical Considerations for a Regenerative Procedure. Available at: www.aae.org/Dental_ Professional/Considerations for Regenerative Procedures.aspx.

38. Ostby BN. The role of the blood clot in endodontic therapy. An experimental histologic study. Acta Odontol Scand 1961;19:324-353.

39. Jung IY, Lee SJ, Hargreaves KM. Biologically based treatment of immature permanent teeth with pulpal necrosis: A case series. J Endod 2008;34(7):876-887.

40. Thomson A, Kahler B. Regenerative endodontics-biologically-based treatment for immature permanent teeth: A case report and review of the literature. Aust Dent J 2010;55(4):446-452.

41. Cotti E, Mereu M, Lusso D. Regenerative treatment of an immature, traumatized tooth with apical periodontitis: Report of a case. J Endod 2008;34(5):611-616.

42. Kahler B, Mistry S, Moule A, Ringsmuth AK, Case P, Thomson A, Holcombe T. Revascularization outcomes: A prospective analysis of 16 consecutive cases. J Endod 2014;40(3):333-338.

43. Shah N, Logani A, Bhaskar U, Aggarwal V. Efficacy of revascularization to induce apexification/apexogensis in infected, nonvital, immature teeth: A pilot clinical study. J Endod 2008;34(8):919-925; discussion 1157.

44. Thibodeau B, Trope M. Pulp revascularization of a necrotic infected immature permanent tooth: Case report and review of the literature. Pediatr Dent 2007;29(1):47-50.

45. Paryani K, Kim SG. Regenerative endodontic treatment of permanent teeth after completion of root development: A report of 2 cases. J Endod 2013;39(7):929-934.

46. Saoud TM, Martin G, Chen YH, Chen KL, Chen CA, Songtrakul K, Malek M, Sigurdsson A, Lin LM. Treatment of mature permanent teeth with 
necrotic pulps and apical periodontitis using regenerative endodontic procedures: A case series. J Endod 2016;42(1):57-65.

47. Wang Y, Zhu X, Zhang C. Pulp revascularization on permanent teeth with open apices in a middleaged patient. J Endod 2015;41(9):1571-1575.

48. Geisler TM. Clinical considerations for regenerative endodontic procedures. Dent Clin North Am 2012;56(3):603-626.

49. Lin LM, Shimizu E, Gibbs JL, Loghin S, Ricucci D. Histologic and histobacteriologic observations of failed revascularization/revitalization therapy: A case report. J Endod 2014;40(2):291-295.

50. Fouad AF, Nosrat A. Pulp regeneration in previously infected root canal space. Endod Topics 2013;28(1):24-37.

51. Chaniotis A. The use of a single-step regenerative approach for the treatment of a replanted mandibular central incisor with severe resorption. Int Endod J 2016;49(8):802-812.

52. McCabe P. Revascularization of an immature tooth with apical periodontitis using a single visit protocol: A case report. Int Endod J 2015;48(5):484-497.

53. Shin SY, Albert JS, Mortman RE. One step pulp revascularization treatment of an immature permanent tooth with chronic apical abscess: A case report. Int Endod J 2009;42(12):1118-1126.

54. Galler KM, D'Souza RN, Federlin M, Cavender AC, Hartgerink JD, Hecker S, Schmalz G. Dentin conditioning codetermines cell fate in regenerative endodontics. J Endod 2011;37(11):1536-1541.

55. Galler KM, Widbiller M, Buchalla W, Eidt A, Hiller KA, Hoffer PC, Schmalz G. Edta conditioning of dentine promotes adhesion, migration and differentiation of dental pulp stem cells. Int Endod J 2016;49(6):581-590.

56. Martin DE, De Almeida JF, Henry MA, Khaing ZZ, Schmidt CE, Teixeira FB, Diogenes A. Concentration-dependent effect of sodium hypochlorite on stem cells of apical papilla survival and differentiation. J Endod 2014;40(1):51-55.

57. Trevino EG, Patwardhan AN, Henry MA, Perry G, Dybdal-Hargreaves N, Hargreaves KM, Diogenes A. Effect of irrigants on the survival of human stem cells of the apical papilla in a platelet-rich plasma scaffold in human root tips. J Endod 2011;37(8):1109-1115.

58. Sato T, Hoshino E, Uematsu H, Noda T. In vitro antimicrobial susceptibility to combinations of drugs on bacteria from carious and endodontic lesions of human deciduous teeth. Oral Microbiol Immunol 1993;8(3):172-176.

59. Takushige T, Cruz EV, Asgor Moral A, Hoshino E. Endodontic treatment of primary teeth using a combination of antibacterial drugs. Int Endod J 2004;37(2):132-138.

60. Hoshino E, Kurihara-Ando N, Sato I, Uematsu H, Sato M, Kota K, Iwaku M. In-vitro antibacterial susceptibility of bacteria taken from infected root dentine to a mixture of ciprofloxacin, metronidazole and minocycline. Int Endod J 1996;29(2):125-130.

61. Sato I, Ando-Kurihara N, Kota K, Iwaku M, Hoshino E. Sterilization of infected root-canal dentine by topical application of a mixture of ciprofloxacin, metronidazole and minocycline in situ. Int Endod J 1996;29(2):118-124.

62. Ruparel NB, Teixeira FB, Ferraz CC, Diogenes A. Direct effect of intracanal medicaments on survival of stem cells of the apical papilla. J Endod 2012;38(10):1372-1375.

63. Althumairy RI, Teixeira FB, Diogenes A. Effect of dentin conditioning with intracanal medicaments on survival of stem cells of apical papilla. J Endod 2014;40(4):521-525.

64. Bose R, Nummikoski P, Hargreaves K. A retrospective evaluation of radiographic outcomes in immature teeth with necrotic root canal systems treated with regenerative endodontic procedures. J Endod 2009;35(10):1343-1349.

65. Diogenes AR, Ruparel NB, Teixeira FB, Hargreaves KM. Translational science in disinfection for regenerative endodontics. J Endod 2014;40(4 Suppl):S52-57.

66. Torabinejad M, Parirokh M. Mineral trioxide aggregate: A comprehensive literature review--part ii: Leakage and biocompatibility investigations. J Endod 2010;36(2):190-202.

67. Yoldas SE, Bani M, Atabek D, Bodur H. Comparison of the potential discoloration effect of bioaggregate, biodentine, and white mineral trioxide aggregate on bovine teeth: In vitro research. J Endod 2016;42(12):1815-1818.

68. Kontakiotis EG, Filippatos CG, Agrafioti A. Levels of evidence for the outcome of regenerative endodontic therapy. J Endod 2014;40(8):1045-1053.

69. Chen YP, Jovani-Sancho Mdel M, Sheth CC. Is revascularization of immature permanent teeth an effective and reproducible technique? 
Dent Traumatol 2015;31(6):429-436.

70. Chen MY, Chen KL, Chen CA, Tayebaty F, Rosenberg PA, Lin LM. Responses of immature permanent teeth with infected necrotic pulp tissue and apical periodontitis/ abscess to revascularization procedures. Int Endod J 2012;45(3):294-305.

71. Kahler B, Rossi-Fedele G. A review of tooth discoloration after regenerative endodontic therapy. J Endod 2016;42(4):563-569.

72. Ioannidis K, Mistakidis I, Beltes P, Karagiannis V. Spectrophotometric analysis of coronal discolouration induced by grey and white mta. Int Endod J 2013;46(2):137-144.

73. Cordeiro MM, Dong Z, Kaneko T, Zhang Z, Miyazawa M, Shi S, Smith AJ, Nor JE. Dental pulp tissue engineering with stem cells from exfoliated deciduous teeth. J Endod 2008;34(8):962-969.

74. Huang GT, Yamaza T, Shea LD, Djouad F, Kuhn NZ, Tuan RS, Shi S. Stem/progenitor cell-mediated de novo regeneration of dental pulp with newly deposited continuous layer of dentin in an in vivo model. Tissue Eng Part A 2010;16(2):605-615.

75. Iohara K, Murakami M, Takeuchi N, Osako Y, Ito M, Ishizaka R, Utunomiya S, Nakamura H, Matsushita K, Nakashima M. A novel combinatorial therapy with pulp stem cells and granulocyte colony-stimulating factor for total pulp regeneration. Stem Cells Transl Med 2013;2(7):521-533.

76. Ishizaka R, Iohara K, Murakami M, Fukuta O, Nakashima M. Regeneration of dental pulp following pulpectomy by fractionated stem/ progenitor cells from bone marrow and adipose tissue. Biomaterials 2012;33(7):2109-2118.

77. Murakami M, Horibe H, Iohara K, Hayashi Y, Osako Y, Takei Y, Nakata K, Motoyama N, Kurita K, Nakashima M. The use of granulocyte-colony stimulating factor induced mobilization for isolation of dental pulp stem cells with high regenerative potential. Biomaterials 2013;34(36):9036-9047.

78. Nakashima M, Iohara K. Mobilized dental pulp stem cells for pulp regeneration: Initiation of clinical trial. J Endod 2014;40(4 Suppl):S26-32.

79. Rosa V, Zhang Z, Grande RH, Nor JE. Dental pulp tissue engineering in full-length human root canals. J Dent Res 2013;92(11):970-975.
80. Gronthos S, Mankani M, Brahim J, Robey PG, Shi S. Postnatal human dental pulp stem cells (DPSCs) in vitro and in vivo. Proc Natl Acad Sci U S A 2000;97(25):13625-13630.

81. Miura M, Gronthos S, Zhao M, Lu B, Fisher LW, Robey PG, Shi S. Shed: Stem cells from human exfoliated deciduous teeth. Proc Natl Acad Sci U S A 2003;100(10):5807-5812.

82. Sonoyama W, Liu Y, Yamaza T, Tuan RS, Wang S, Shi S, Huang GT. Characterization of the apical papilla and its residing stem cells from human immature permanent teeth: A pilot study. J Endod 2008;34(2):166-171.

83. Huang GT, Al-Habib M, Gauthier P. Challenges of stem cell-based pulp and dentin regeneration: A clinical perspective. Endod Topics 2013;28(1):51-60.

84. Mao JJ, Kim SG, Zhou J, Ye L, Cho S, Suzuki T, Fu SY, Yang R, Zhou X. Regenerative endodontics: Barriers and strategies for clinical translation. Dent Clin North Am 2012;56(3):639649.

85. Conde MC, Chisini LA, Demarco FF, Nor JE, Casagrande L, Tarquinio SB. Stem cell-based pulp tissue engineering: Variables enrolled in translation from the bench to the bedside, a systematic review of literature. Int Endod $\mathrm{J}$ 2016;49(6):543-550.

\author{
Corresponding Author: \\ Louis M. LIN \\ Department of Endodontics \\ New York University College of Dentistry \\ 345 East 24th Street New York, NY 10010 USA \\ Phone: +1-(212) 998-9687 \\ e-mail:1m17@nyu.edu
}

